\title{
Research on the Teaching Reform and Talent Cultivation Methods of Drama and Film Major in Colleges and Universities
}

\author{
Cao Zhen \\ Media and Communication College, Xi'an Peihua University, 710125
}

\begin{abstract}
Keywords: Colleges and Universities; Drama and Film Literature; Teaching Reform; Talent Cultivation
\end{abstract}

\begin{abstract}
The drama and film literature major is an important subject in the higher education system. With the continuous improvement of people's living standards, people's pursuit of spiritual and cultural levels has moved to a higher level. As a typical representative of artistic works, drama and film literature can not be created without the training of high-level talents. Colleges and universities shoulder the important task of cultivating talents for socialist modernization. How to do a good job in the reform of the construction of drama and film literature in colleges and universities in a new historical period is a problem worthy of attention of all educators. This article briefly discusses the problems in teaching reform and talent cultivation of drama and film literature major in colleges and universities and gives some measures to achieve the role of reference and improvement.
\end{abstract}

\section{Introduction}

In recent years, with the development of China's economy and society, people's demand for spiritual and cultural life has also shown a trend of rapid development on the basis of continuous improvement in the level of material life. How to meet people's increasing demand has risen to the height of the national level and has been given full attention. Among these, a very critical link is how to improve the ability and literacy of professionals in China's drama and film literature, and improve their professionalism and creative ability. The development of modernization, especially in the field of art, cannot be separated from a large pool of talent.

China's higher education shoulders the burden of cultivating talent for the country. With the development of society, higher education institutions have been given more social responsibilities. After years of continuous development and improvement in the cultivation of drama and film literature professionals, we have achieved encouraging results in many aspects. However, it should also be clearly understood that there is not a small gap between our talent training and the quality of talent output and social needs. How to do a good job in teaching reform and talent cultivation of drama and film literature in colleges and universities is a social issue, and it is more an education issue.

\section{Main Problems Existing in the Construction of Drama and Film Literature Speciality in Colleges and Universities}

The scores achieved in college drama and film literature majors need not be described here. As a teacher who has long been engaged in the teaching of drama and film literature in colleges and universities, based on the summarization of long-term teaching practice, the author believes that the current drama and film literature majors in China have the following problems.

Ideological Issues. As an important part of China's higher education system, the drama and film literature major plays a very important role in promoting social and economic development. However, for a long time, traditional ideology has a prejudice against the understanding of related professions. First of all, many people think that the main force for promoting social progress is science and engineering and other related disciplines. Even many people think that the various majors of art are only auxiliary subjects, and there is basically no substantial role in promoting social progress. There are a lot of people who hold this idea. Under the drive of colored glasses, the 
drama and film literature major encountered many problems in its development. For example, the professional construction is not taken seriously. The hardware and software investment conditions are limited and the strategy to implement talents going out has not been promoted. The existence of problems in ideological concepts has its profound historical and social factors. With the development of the times, this concept will gradually fade out of people's cognitive scope. The majority of colleges and universities should give full attention to the existence of this issue. Only by facing up to the problem can we solve the problem effectively.

Student Source Issues. The drama and film literature major is a comprehensive and highly specialized profession, requiring practitioners to have very good congenital conditions and acquired efforts. Under the background of the transition from elite education to popular education in China's higher education, various universities and colleges have continuously expanded the scale of enrollment, which has reduced the criteria for talent screening and the entry threshold to some extent. At the same time, many students do not have the ability to learn in the cultural classes at the time of school. In order to receive higher education, they have to reduce the requirements of cultural classes and choose the art major. Their desire for studying art is not strong, but more is to get an opportunity to accept higher education through colleges and universities, so as to create certain conditions for future employment. The decrease in the quality of students is a reality in all drama and film literature major in colleges and universities.

Skills Requirements. With the acceleration of the social division of labor and the improvement of people's appreciation, the development of any kind of art is moving toward a refined trend. However, on the other hand, our professional construction puts together many disciplines in different directions. Of course, this is partly due to the restrictions on the school's own conditions. However, the deeper aspect is that we have not yet fully recognized the demand for refined development. Drama and film literature have their own characteristics. We can not ignore their significant differences when recognize their commonalities among the three. Fine-scale development requires us to conduct more meticulous research on each professional direction in the drama and film literature major. The research content can be carried out in a deeper, broader and higher level around professional orientation. At present, many colleges and universities have conducted theoretical research in related directions and have carried out bold and effective practices. They have achieved notable results, but most universities still follow the old professional settings.

Course Issues. Problems in the curriculum are currently prominent. Whether it is in the course content or in the course progress, there are many problems in our curriculum. First of all, the selection of course materials is rather obsolete. Nowadays, whether it is drama, film or literature, its development is changing with each passing day. Compared with it, our textbooks is obviously lagging behind. How to adopt the development of live drama and film literature into the selection and application of teaching materials is an urgent task for education and teaching. At the same time, there are irrational places in our curriculum, over-emphasizing the importance of theoretical learning, but ignoring the most critical practice links.

Socialization of Employment. The problem of employment socialization is to consider the education and teaching ideas from the perspective of student employment. In recent years, despite the society's increasing demand for drama and film literature professionals, the number of talented people in our relevant universities is also increasing, but the employment status of students is not satisfactory. One of the most important reasons is that there are deficiencies in our talent training mechanism. Colleges and universities do not fully integrate social needs and personnel training, which has caused the society to urgently require a large number of related professionals but has not found a suitable source. On the other hand, schools have cultivated a large number of talents, but they found that there are big differences between comprehensive quality of personnel training and social and corporate requirements. This should be a win-win situation, but the end result is uneasy. The problem of structural barriers has gradually emerged. The first one is the gap between talent training and social need. How to achieve leapfrogging and how to achieve a well-targeted talent cultivation mechanism is a systematic project that requires the joint efforts of the entire society and the school. How to achieve good results between talent cultivation and social needs is a new topic in 
the field of talent cultivation in the new era.

\section{Research on Reform Measures and Talent Cultivation Program}

In view of the problems existing in China's drama and film literature major and the personal experience and teaching practice of the author, the author believes that reform measures and personnel training strategies for drama and film literature in China should focus on the following aspects. Therefore, based on our own advantages and disadvantages, schools should explore an innovative development path that suits our own conditions and improve the quality of education and teaching to occupy a place in fierce competition.

Increase Investment in Education and Teaching. Schools should pay full attention to the development and construction of drama and film literature major whether it is in teachers or the capital investment. In the past few years, we have seen many shortcomings in the lack of investment in the drama and film literature major. We must look at issues in discipline construction with a sense of urgency. In terms of thinking, the initiative of teacher education and teaching is mobilized, long-term planning for professional development is made from the school level and efforts are made to form systematic input in curriculum setting, teacher training, and other aspects.

Consolidate Cultural Literacy. The drama and film literature major is a comprehensive professional discipline. Cultural heritage has a very important basic role in drama and film literature. As we all know, many literary and art workers are particularly good in one area but they are hardly artists. The most important reason is the lack of cultural heritage. The influence of culture on people is accomplished in a subtle manner, which influences a person's speech, behavior and artistic charm. In this era of rapid development, only those literary and art workers with deep cultural abilities can experience the true scientific connotation and deep-seated needs of art. Art workers who ignore the cultural heritage will make their own literary and artistic creation narrower and narrower. In the end, they has to revert to seeking the development of art in the cultural heritage. Therefore, from the beginning, teachers should focus on strengthening students' cultural heritage and nurturing their related consciousness as barren culture directly restricts the development of art in future. Teachers should create as many opportunities for students as possible, so that they can strengthen the study of cultural knowledge, use the classroom and spare time for a wide range of activities, learn from others and develop in a balanced manner.

Strengthen Students' Ability. At present, there is a problem that schools generally emphasize on theoretical knowledge and ignore teaching practice in colleges and universities in China, which resulted in a weak overall ability of students we cultivated. Therefore, in education and teaching, teachers must strengthen the ability of students. However, teachers mainly draw on the relevant experience of foreign countries in the education and teaching of art-related majors as there are not many things of our own. How to combine the characteristics of Chinese students with the characteristics of teaching, and use effective means to cultivate students' comprehensive ability is the most important thing in our current education and teaching reform. In education and teaching, teachers must pay special attention to cultivating students' comprehensive ability and lay a good foundation for them to enter society in the future. Education and teaching are based on the overall education and teaching goals, but students' individual differences must also be fully taken into account. This difference may come from students' understanding of education and teaching, and it may also come from differences in students' physical and mental skills. Teachers should scientifically control the progress of teaching and not allow backward students to produce fear of learning. At the same time, schools must change the phenomenon in which teachers are dominant in traditional education and teaching, fully mobilize students' autonomy and creativity to stimulate students' interest in learning, making students be the core of education and teaching.

Strengthen Teachers Team. Teachers are the foundation for carrying out all education and teaching activities. Therefore, schools should spare no efforts to strengthen the teaching staff. According to the author's investigation, the professional teachers of drama and film literature have problems of weak academic development, ambiguous professional features and relatively backward professional knowledge, which has severely restricted the development of drama and film literature. 
Schools must continue to strengthen the relevant teachers team, strengthen professional teachers' moral awareness and urge teachers to consciously enhance professional theoretical knowledge and professional teaching skills. On the other hand, schools must strengthen teachers' retraining and continuing education work, formulate long-term goals and plans for the development of teachers and improve the overall level of the teachers' ability. Besides, schools should also appropriately dedicate funds to professional construction and strengthen the level of hardware and software construction for professional teaching.

Strengthen the Strategy of Going Global. Art comes from life but it is higher than life. Therefore, many categories of art are inseparable from our working life. How to effectively make education and teaching and students' ability to meet the needs of society and people's lives is the key to the sustained and healthy development of related professions. How to allow students to learn in social practice, to strengthen what they have learned and to plan their employment through social practices is a key component of the strategy of going global. At present, the school-enterprise cooperation mode has become a platform and bridge for many students to go out. In terms of their implementation, overall satisfactory results have been achieved. Schools must actively explore the school-enterprise cooperation mode of the drama and film literature, and boldly innovate in practice. Besides, efforts are made to explore other steps and methods so that students and teachers have more opportunities and platforms to form a positive interaction between professional knowledge and market elements and contribute to the development of China's drama and film literature major.

\section{Conclusion}

Regardless of the current trend of the development of universities in our country or from the perspective of professional construction, there are many drawbacks in the education and teaching of drama and film literature. We must seize the opportunity of the current reform and development of higher education, change our concepts and provide advice and suggestions for the construction and development of disciplines to jointly improve the level of comprehensive development of higher education in China.

\section{Reference}

[1]H. W. Liu. An Initial Study on the Teaching of Drama and Film Performance in the New Age [J]. Sichuan Drama. 2012(01).

[2] L. Sui and J. Xu. Building Self-Confidence and Mastering Skills - A Study of Language Teaching in Performance Practice Teaching [J]. Journal of Beijing Film Academy. 2012(03).

[3] L. Sui. The Freedom of Imagination - A Preliminary Exploration of Performance Teaching [J]. Journal of Beijing Film Academy. 2011(04).

[4] K. Y. Zhong. Exploration and Practice of Audiovisual Experiment Teaching Mode in Film and TV Art Universities [J]. Experimental Technology and Management. 2007(04).

[5] F. Z. Chen. Reflections on Cultivating Innovative Talents of Drama and Film Literature [J]. Debate, 2013.

[6] P. Zhang and X. H. Zhang. Comparative Literature [M]. Changchun: Jilin People's Press, 2011, (10).

[7] X. H. Zhang. The Direction and Exploration of Bilingual Teaching Mode in Comparative Literature [J]. Theoretical Observation, 2012, (01).

[8] J. C. Wang. Talking about the Cultivation of Talents in Drama and Film Performance [J]. China Press, 2011(08). 